care of the mentally handicapped in all mental handicap hospitals and units.

(3) That nurses already working in this area or intending to do so, should be encouraged and enabled to gain further experience or the RMN qualification through secondment to psychiatric hospitals and established courses.

(4) That the ENB promote post-basic training courses in psychiatric aspects of the care of the mentally handicapped.
In the long term we consider that there needs to be a major review of nurse training in mental handicap which takes account of the different roles which will be played by mental handicap nurses as new patterns of care evolve and the possibility that different courses will be required for nurses wishing to pursue careers in different aspects of the service.

\title{
Dr Anatoly Koryagin
}

Dr Anatoly Koryagin, the Russian psychiatrist distinguished for his struggles against the political abuse of psychiatry in the USSR is, following his release, at present domiciled in Switzerland. He has agreed to speak to the title "The involvement of Soviet Psychiatry in the persecution of dissenters" at the College's Autumn Quarterly Meeting at Kensington Town Hall, on Thursday, 29 October 1987 at 11.45 a.m. He will, on that occasion, be presented with his certificate of Fellowship of this College.

\section{Obituary}

Editor: Henry R. Rollin

Fernando Arroyave-Portella, Consultant Psychiatrist, Alcoholic Unit, Warneford Hospital, Oxford.

Fernando Arroyave died aged 53 years on 11 April 1987. He did so in the same way he had lived: with flair and a sense of the dramatic. The first Fellow of the Royal College of Psychiatrists to have a heart transplant (at Harefields Hospital) he whispered, as he was being wheeled into theatre: "I am not going without putting up a good fight". And fight he did; alas this last battle he was unable to win. And he should have, because he was a generous, warm, thoroughly professional and fiercely independent man. He never ceased to be a Colombian. Gone with him are his bonhomie, the impish quality of his laughter and the teasing and forthright delivery of his usually well-timed profanities.

From a medical family, Columbian in origin and trained in medicine at Salamanca University, Fernando Arroyave was one of that selected band of young Spanish-speaking doctors who came to work under Felix Letemendia, that Mecenas of psychiatry, in the memorable Littlemore Hospital of the early and middle 1960 s, where it was not uncommon to see Gilbert Ryle, Carolus Oldfield, Richtie Russell, or May Davison quietly walking towards the Old Library to deliver a lecture to the trainees.

With a solid background in biological psychiatry and in electro-encephalography Fernando Arroyave came to choose, as his metier, one of the toughest of psychiatric disorders: alcoholism. Aware of the psychodynamic dimensions of the problem he decided to train as a psychoanalyst. He threw himself into his new field with his usual panache and determination, and after hundreds of training hours and thousands of miles down the M40 he emerged, at the other end, still Latinoamerican and still mercurial, perhaps greyer at the temples, but fully trained in both Jungian and group psychoanalysis.

His research into alcoholism was practical and full of common sense. He demonstrated, for example, that shorter admissions for assessment and drying out were as successful as longer ones. In the euphemistic world of the 1970s, when alcoholic units became 'Drink Problem Clinics' and 'Controlled Drinking' the new fashion, his sense of clinical balance and realism prevailed, and he wrote vigorously in favour of total abstinence.

He did not think much of those colleagues who made it easy for themselves by accepting for treatment only the few 'clients' that complied with overselective criteria. He believed that alcoholic units must offer the full range of services including acute medical and psychiatric care. Using this flexible admission policy he managed to collect one of the largest cohorts of alcoholic patients in the country. He was actively analysing this rich source of clinical information when he was finally smitten by disease. He was fond of saying that he who forgets his general psychiatry is no longer of any use even to alcoholism. 